\title{
Editorial
}

\section{A new academic year}

This is the time of year when most universities have just started up their courses. New students roam the corridors and are getting their first impression of academic life, faculty staff, fellow students and public health nutrition as a topic. How can we be good teachers and guide them in their future endeavours? Are universities today structures that provide possibilities for good leadership or are they structures without an ethos?

\section{The university transformation}

The last few years have in most European countries meant a severely increased workload for all academic staff, adhering to the Bologna Declaration of June 1999. The priorities of the Bologna process included the introduction of the three cycle system (bachelor/master/doctorate), quality assurance systems and a joint recognition of qualifications and periods of study over Europe. In practice, this has meant a change in admission systems and changes of curricula for all courses, including a whole new way of looking at student learning outcomes, assessment and examinations. Obviously lots of energy and time has gone into this process at all levels, including that from university leadership and department chairs, but probably most of all from university teachers. The process has still not been rapid enough. The European University Association states that the reform of structure seems to have been taking place, rather than a change in substance and content, and without a link to institutional strategic objectives, $^{(1)}$.

\section{Where did the academic ideals go?}

Let us take a look at the universal academic norms and ideals where it all began, namely with an academic structure building on consensus, academic freedom and autonomy, professionalism, and the provision of knowledge regarding what is best for society. Recent changes include going from elite to mass universities, from professional leadership towards market-geared leadership, from collegiality to management, and towards a very strong focus on excellent research centres ${ }^{(2)}$.

Academic leadership becomes a new task at a time when the donors of grant funds dictate the research and when the structural and content changes in curricula become a tremendous burden to academic staff, leaving little time for development of the topic as such. A Swedish female department chair stated recently: '... our work is defined by economy. It feels as if research, teaching and societal collaboration have to give. It is not good that we are just staring at figures. On the other hand, we are at the bottom now. Things have to turn, become better' ${ }^{\text {(2) }}$.

\section{Life beyond Bologna in public health nutrition training and academic development in Europe}

We can see the light at the end of the tunnel in European academic life. As academic staff, we have actually survived the major transformation of our courses and university structures. We have worked hard and in many cases been occupied with counting our Euros rather than defining our ethos or defending our academic freedom. In order to stabilise future healthy developments in the European population and a true mobility of public health nutrition workers, we have seen the need to ensure an efficient and comparable training in public health nutrition, ensuring a future workforce with the ability to meet demands from the market as well as from academia. The role of this journal in that regard becomes crucial and we need to publish and discuss papers on workforce development ${ }^{(3-5)}$ as well as papers on research priorities and on public policy developments, and promote a healthy debate and lobbying. A lot of work has previously gone into trying to establish consensus in this area over Europe, creating structures for student and teacher exchange and building teaching consortia $^{(6,7)}$. A new world association for public health nutrition is forming. As far as European training programmes go, now that the international structure is there, academically in Europe through the Bologna process, and worldwide through the new World Public Health Nutrition Association, we have new possibilities to collaborate.

In the midst of a confusing and straining reality in academia, let us be wise enough to remember the important role of the good teacher. Let us also remember the importance of freedom of research and to show our students, the future public health nutrition workforce, how and why they should work towards the good for society.

Agneta Yngve Editor-in-Chief

\section{References}

1. Crosier D, Purser L \& Smidt H (2007) Trends V: Universities Shaping the European Higher Education Area. Brussels: European University Association; available at http:// www.eua.be/fileadmin/user_upload/files/Publications/ Final_Trends_Report_May_10.pdf 
2. Högskoleverket (2008) Fribetens pris- ett gränslöst arbete. En tematisk studie av de akademiska lärarnas och institutionsledarnas arbetssituation. Report no. 2008:22R. Stockholm: Swedish National Agency for Higher Education.

3. Fox A, Chenhall C, Traynor M, Scythes C \& Bellman J (2006) Public health nutrition practice in Canada: a situational assessment. Public Health Nutr 11, 773-781.

4. Haughton B \& George A (2008) The Public Health Nutrition workforce and its future challenges: the US experience. Public Health Nutr 11, 782-791.

\section{In this issue}

Television and other forms of electronic media have become ever-present influences on our lifestyles, the information we receive and our subsequent view of the world. It is not surprising then that these media are an important focus of analysis and debate in the context of public health nutrition, in particular concerning their contribution to obesogenic environments and their related influence over consumption behaviour.

Use of these media to selectively market obesogenic foods and beverages to children has been widely criticised as being exploitative and inappropriate. This issue publishes an important short communication from Swinburn et $a l^{(1)}$ (collectively representing the International Obesity Taskforce Working Group on Marketing to Children) outlining the 'Sydney Principles'. This set of seven principles, developed based on a children's rights-based approach, is promoted for use as a benchmark action to reduce marketing to children. The authors call for the formation of an International Code on Food and Beverage Marketing to Children, based on these principles. This paper should be compulsory reading for students, practitioners and academics as a source of conceptual clarity on this issue. More importantly, it should be a rod to the back of policy makers worldwide who are charged with the responsibility of protecting the interests of our children and the public health.

It is no surprise that watching television is a behaviour that increases the risk of becoming and staying overweight or obese. Xu et al. ${ }^{(2)}$ present results from a crosssectional study among high-school students in China that supports this relationship. Halford et $a l^{(3)}$ provide evidence from a study in the UK that obese and overweight children are more responsive to food promotion, stimulating the intake of energy-dense snacks. The evidence in support of the 'Sydney Principles' is clearly mounting.

Television is not the only vehicle for influencing consumers' food and beverage purchasing and consumption behaviours. In this issue, Mazur et al. ${ }^{(4)}$ present the
5. Hughes R (2008) Workforce development: challenges for practice, professionalization and progress. Public Health Nutr 11, 765-767.

6. Margetts B, Warm D, Yngve A \& Sjostrom M (2001) Developing an evidence-based approach to Public Health Nutrition: translating evidence into policy. Public Health Nutr 4, 1393-1397.

7. Yngve A, Warm D, Landman J \& Sjostrom M (2001) A European Master's Programme in Public Health Nutrition. Public Health Nutr 4, 1389-1391.

doi:10.1017/S1368980008003194

findings of a study of the impact of point-of-purchase advertising on food purchases by students in primary and secondary schools in Poland. Lozada et al. ${ }^{(5)}$ present evidence from a study in Mexican schools indicating that school food supplies are not immune to vendors marketing obesogenic foods. School food supplies and associated marketing need ongoing scrutiny. The mantra of individual responsibility often promulgated by those resistant to legislative protection of consumers is not credible in the context of children and the environments they occupy.

The 'Sydney Principles' have application in all settings where advertisers exploit sophisticated marketing strategies to influence the food choice and related health of children and the broader public.

Roger Hughes Deputy Editor

\section{References}

1. Swinburn B, Sacks G, Lobstein T, Rigby N, Baur LA, Brownell KD, Gill T, Seidell J \& Kumianyika S; International Obesity Taskforce Working Group on Marketing to Children (2008) The 'Sydney Principles' for reducing the commercial promotion of foods and beverages to children. Public Health Nutr 11, 881-886.

2. Xu F, Li J-Q, Ware RS \& Owen N (2008) Associations of television viewing time with excess body weight among urban and rural high-school students in regional mainland China. Public Health Nutr 11, 891-896.

3. Halford JCG, Boyland EJ, Hughes GM, Stacey L, McKean S \& Dovey TM (2008) Beyond-brand effect of television food advertisements on food choice in children: the effects of weight status. Public Health Nutr 11, 897-904.

4. Mazur A, Telega G, Kotowicz A et al. (2008) Impact of food advertising on food purchases by students in primary and secondary schools in south-eastern Poland. Public Health Nutr 11, 978-981.

5. Lozada M, Sánchez-Castillo CP, Cabrera GA, Mata II, Pichardo-Ontiveros E, Villa AR \& James WPT (2008) School food in Mexican children. Public Health Nutr 11, 924-933. 